\title{
Investigating the Interplay between Age Range and Vocabulary Learning among EFL Learners
}

\author{
Hamed Barjesteh \\ Department of English Language Literature, Islamic Azad University, Ayatollah Amoli Branch, Mazandaran, Iran \\ Lida Farsi \\ Department of English Language Literature, Islamic Azad University, Ayatollah Amoli Branch, Mazandaran, Iran
}

\begin{abstract}
The present study aimed to examine the relationship between age range and vocabulary learning among pre-intermediate Iranian EFL learners. To this aim, 50 pre-intermediate Iranian EFL learners, male $(\mathrm{N}=20)$ and female $(\mathrm{N}=30)$, were selected from a private language institute based on their performance on the Oxford Placement Test (OPT). They were divided into two groups: teenager and adult learners. Before intervention, a pretest of vocabulary was conducted to determine students' vocabulary knowledge. Then, vocabularies were presentenced in dialog, word power and reading texts using a monolingual dictionary in five sessions interval for the both groups. After the intervention, a post-test of vocabulary was administered to examine the possible improvement. The data obtained from the administration of the pre-test and the post-test were analyzed using SPSS software. The results revealed that there was no significant relationship between the performance of teenager and adult groups in their vocabulary learning; and there was no significant difference between the performance of teenager and adult groups in their vocabulary learning. This research potentially has some implications that may help English language teachers, students, EFL learners and educational syllabus designers.
\end{abstract}

Index Terms —interplay, age range, vocabulary learning, pre-intermediate, EFL learners

\section{INTRODUCTION}

Learner's differences as well as age, gender, proficiency level and so on have a considerable role in the process of language teaching and learning. Theoretically and practically, learners' age is determined as one of the influential and crucial issue in the area of second or foreign language learning (Munoz, 2010). He also mentioned that the age impacts have been the research object basically in natural contexts where the immigrants' proficiency level in the target language has been considered on the foundation of their age of arrival in the ESL and EFL communities. According to Torras, Tragant and García (1997), the general idea relating to the age at which children should start learning a foreign language in schools is impressively affected by findings gained in naturalistic language learning contexts. The effects of age on different fields of language learning as well as main skills and sub-skills have been taken into account (Sadeghi\&Taghi Attar, 2013; Shoshtari, Samian \& Khazaei, 2013). In the present study, the effect of age range on vocabulary learning was examined.

Learning vocabulary is one of the most important aspects of acquiring a language without which communication would be impossible. Actually, vocabulary is no longer regarded "an ignored dimension of language learning" (Meara, 1980, p. 221) but rather than has transformed into section and parcel of successful English language teaching and learning (Coady \& Huckin, 1997). Learning vocabulary items is the key to learn a foreign language and this is received by great attention from the side of both the learners and instructors. According to Richards and Renandya (2002), vocabulary is regarded as a key element of language proficiency and supplies much of the basis for how well students speak, listen, read and write. Increasing vocabulary knowledge, as Sadeghi (2013) assert, is considered the basis of language learning. Inadequate knowledge of vocabulary has been the source of problem for many students in the process of language learning (Maftoon, Hamidi, \& Sarem, 2012).

Acquiring a vast knowledge of vocabulary items has been the main concern a foreign language learner faces (Ebrahimpourtaher \& Eissaie, 2015). In other words, vocabulary learning is a complicated, gradual and time-consuming process. The optimal age for learning vocabulary may be an important issue in accelerating this process. To fill the gap, this study attempted to examine the possible relationship between age range and vocabulary learning among preintermediate Iranian EFL learners.

\section{LITERATURE REVIEW}

Different scholars defined vocabulary differently. Some of these definitions are provided. Kamil and Hiebert (2005) regard vocabulary as the knowledge about words as well as words meaning which might be presented in receptive and productive forms. Kamil and Hiebert (2005, p. 2-3) use it to refer to "the kind of word that students must know to read increasingly demanding text with comprehension.” 
Knowing a word, as Harmer (1991) puts it, entails knowing about word use, meaning, and word formation as well as grammar. Stahl (2003) defines the vocabulary as the knowledge of words in the both productive and receptive forms. Moreover, Nunan (1999) defined vocabulary as a list of target language words and they should be acquired in the process of language learning. In similar vein, Adger (2002) believes how people use and store words are important in addition to how they learn words and the relationship between them.

The role of vocabulary learning is prominent is the process of language teaching and learning. As Lewis (1993) claims that "lexis is the core or heart of language" (p. 89). In order to learn an L2/ FL second or foreign language, vocabulary seemsthe most central and critical to the typical language learners (Zimmerman, 1997). Vocabulary items are the basic building blocks of any language and the meaning components forming larger structures like phrases, clauses, sentences,paragraphs, and the whole text (Read, 2000). Specifically, Schmitt (2010) points out that as learners enhance greater fluency and expression in English, it is important for them to learn more productive vocabulary knowledge and to improve their own personal vocabulary learning strategies. Having good knowledge about various types of vocabulary learning strategies and applying them in appropriate situations, students can expedite the process of vocabulary learning (Ranalli, 2003). Applying strategies independently of a teacher is the most influential method to learn vocabulary (Nation, 2001).

Vocabulary plays an important role in foreign language learning. Knowing vocabulary items has a key role in the success of language learning. (De Bot, Paribakht, \&Wesche, 1997). EFL learners should consider the development of rich vocabulary the crucial element of language learning (Nunan, 1991, p. 118). Vocabulary becomes an essential part in foreign language learning. Schmitt and McCarthy (1997) have drawn attention to the fact that vocabulary learning has been regarded as one of the most important components of L2 acquisition. Similarly, Rubin (1987) points out that at the heart of mastering a foreign language is vocabulary learning. In line with that, as Rubin and Thompson (1994, p. 79) argue, "Without knowing a lot of words, mastering the target language is quite difficult". Many researchers believe, vocabulary knowledge is not a single but rather a multifaceted and complex construct that involves understanding of a wide range of word knowledge and aspects (Nation, 2001; Read, 2000).Wilkins (1972) argues that "Without grammar, very little can be conveyed and without vocabulary, nothing can be conveyed" (p.11). According to Nation (2001), learners' final attainment in learning a foreign language depends on whether they can master a certain amount of vocabulary. The objective of the course determines the amount of vocabulary items to be taught.

Age is one of the many individual difference types which has its role in language learning. As Ellis (2008) asserts, younger language learners are more successful in the process of language learning. Proponents of the Critical Period Hypothesis stress the fact that language acquisition should occur before puberty in order to have optimal language learning on the part of the learners (Sarem \& Hamidi, 2010). This optimal age is said to be within the first ten years of life, when the brain retains its plasticity (as cited in Ellis, 2008).

Researchers have concentrated on the need for language learners in order to improve the vocabulary learning, especially in second language acquisition (Schmitt, 2000). Researchers have proposed various vocabulary learning strategies for different situations. For example, Schmitt (2000) mentions the following two purposes: (1) strategies for discovering the meaning of a new word consisting of determination and social strategies, and (2) strategies for consolidating a word including social, memory, cognitive and metacognitive strategies. In determination strategies, learners use the guessing technique to discover the meaning of the words in the context. In social strategies learners ask for others' help to discover the meaning of the new words. Learners also need to use a variety of social, memory, cognitive and metacognitive strategies to consolidate their vocabulary knowledge. An instance of the use of social strategies for consolidating is cooperative learning in groups practicing the words with each other. Relating the word to some items which have been previously learned is an example of memory strategies. In cognitive strategies learners try to learn the new words through repetition and using mechanical means such as word lists, flash cards, and vocabulary notebooks. Finally, through the use of metacognitive strategies learners control and evaluate their own learning (Schmitt, 2000).

At first, this period, as claimed by Lenneberg (1967), was the same as the period accounted for the concept of lateralization of the language function happening mostly to the left hemisphere of the brain. Research on cases who suffered brain injuries showed that damage to this particular hemisphere (left side) caused few speech disorders; however, fast repair was witnessed in the case of children but not adults (as cited in Lenneberg, 1967. Nevertheless, later work by Whitaker, Bub, and Leventer (1981) did not seem to agree on the exact age of lateralization, leading to doubts concerning the neurological foundation of the CPH. This controversy emphasizes on both whether there are significant differences in L2 learning due to age, and also on the theoretical elaborations for those distinguishes which investigators argue to have found. Supporting this fact, Larsen-Freeman and Long (1991) claim that age is only a basic matter for theory building in SLA research studies, and also for policy-making in educational settings.

Different studies have been conducted about the role of age in second or foreign language learning. Chen (2014) examined strategies in language learning employed by (EFL) learners at different educational settings and investigated the impact of age on strategies in language learning. His findings indicated that meaningful relationships existed between the use of memory strategies, compensation strategies, metacognitive strategies, and affective strategies and age groups and. In one particular study done by Riazi, Sadighi, and Zare (2005) it turned out that there was a positive relationship between students' proficiency level and their use of vocabulary learning strategies, especially those 
strategies that were cognitively deeper. Age is also another factor affecting students' use of vocabulary learning strategies. In another study which was done by Riazi, Sadighi, and Zare(2005), it was found that as the age of the students increased, their use of cognitive strategies increased as well.

Research Questions and Related Hypotheses

This research was aimed to find out the relationship between age range and vocabulary learning among preintermediate Iranian EFL learners. The research questions were as follow:

RQ1. Is there any significant relationship between the performance of teenager and adult groups in their vocabulary learning?

RQ2. Is there any significant difference between the performance of teenager and adult groups in their vocabulary learning?

In accordance with the research questions mentioned above, the following null hypotheses were formulated.

H01. There is no significant relationship between the performance of teenager and adult groups in their vocabulary learning.

H02. There is no significant difference between the performance of teenager and adult groups in their vocabulary learning.

\section{METHODOLOGY}

\section{Participants}

To research the purpose of the study, 50 out of 65 pre-intermediate Iranian EFL learners, male $(\mathrm{N}=20)$ and female $(\mathrm{N}=30)$ were selected from a private language institute in Amol, Mazandaran based on their performance on the Oxford Placement Test (OPT). Afterwards, they were divided into 2 groups based on their age: teenagers (13 to 16) with the average of 12.8 and adults (18-22) with the average of 21 . The learners' experience in language learning was at least 1 year. The sampling procedure was non-random and purposeful.

\section{Instruments}

There were two instruments in this study. The first one was an Oxford Placement Test (Syndicate, 2001). This test was applied to homogenize language learners in the present study based on pre-intermediate level. This test consisted of 60 items in three areas: vocabulary, reading and grammar. The OPT is a highly reliable test. The reliability of the OPT has been reported by Hamidi (2015) to be .82 using KR-21 formula having seventy students studying New Interchange 3 and .86 using a test-retest method with a 2-week interval having ninety students almost finishing Four Corners 4 , both of which show high reliability index.

Two 30-item tests which were applied to measure the learners' vocabulary knowledge served as the second instrument of this study. The tests format was multiple choice items and they were teacher-made tests. They were used as pre- and posttests. The frequent words were selected from second interchange by Richards (2005). The reliability of pre- and posttests were calculated, using $\mathrm{Kr}-21$ formula, in pilot tests were about 0.72 and 0.69 , respectively. The time limit for doing each of the vocabulary test was 25 minutes.

Data Collection Procedure

The whole procedures of this study were performed in 8 sessions. The first step was to explain the purpose and whole procedures of this study orally. Then the OPT was administered to homogenize the participants. 50 pre-intermediate EFL learners were selected and they were divided into two groups: teenager and adult. Afterwards, a vocabulary pretest was administered. In the next section, the teacher taught the vocabularies in dialog, word power and reading texts through using a monolingual dictionary in five sessions. Both groups performed this procedure. In the last step, the vocabulary posttest was administered.

Data Analysis

Statistical Package for Social Science (SPSS) version 21 was used in analyzing the data. The descriptive statistics (mean and standard deviation) and inferential statistics were calculated. To examine the relationship between two variables, the Pearson Product Moment was used. To examine the meaningful difference between two variables, an Independent t-test was used.

\section{Results}

Table 1 indicates the correlation between teenager group and vocabulary learning. The sig value (2-tailed) reveals that there is no correlation between the two groups as $\mathrm{p}=.61$ is greater than the required .05 . In this regard, it can be stated that there is no significant relationship between the performance teenager group and their vocabulary learning. 
TABLE 1

PEARSON CORRELATION OF TEENAGER GROUP AND VOCABULARY SCORES

\begin{tabular}{|c|c|c|c|}
\hline & & Teenager group & Vocab scores \\
\hline \multirow{3}{*}{ Teenager group } & Pearson Correlation & 1 & .036 \\
\hline & Sig. (2-tailed) & & .618 \\
\hline & $\mathrm{N}$ & 25 & 25 \\
\hline \multirow{3}{*}{ Vocab scores } & Pearson Correlation & .036 & 1 \\
\hline & Sig. (2-tailed) & .618 & \\
\hline & $\mathrm{N}$ & 25 & 25 \\
\hline
\end{tabular}

Table 2 reveals the correlation between the adult group and vocabulary learning. The sig value (2-tailed) reveals that there is no correlation between the two groups as $\mathrm{p}=.58$ is greater than the required .05 . In this regard, it can be stated that there is no significant relationship between the performances of adult group in their vocabulary learning.

TABLE 2

PEARSON CORRELATION OF ADULT GROUP AND VOCABULARY SCORES

\begin{tabular}{llll}
\hline & & Adult Group & Vocab Scores \\
\hline \multirow{3}{*}{ Adult Group } & Pearson Correlation & 1 & .034 \\
\cline { 2 - 4 } & Sig. (2-tailed) & 25 & .583 \\
\cline { 2 - 4 } & $\mathrm{N}$ & .034 & 25 \\
\hline \multirow{3}{*}{ Vocab Scores } & Pearson Correlation & .583 & 1 \\
\cline { 2 - 4 } & Sig. (2-tailed) & 25 & 25 \\
\cline { 2 - 4 } & $\mathrm{N}$ & 25 & \\
\hline
\end{tabular}

Table 3 indicates the result of independent sample t-test of the two groups in the pre-test. The p value (.789) in the sig (2-tailed) is greater than .05, so it can be stated that there is no statistically significant difference between the performance of teenager and adult groups in the vocabulary learning pre-test.

TABLE 3

INDEPENDENT SAMPLES T-TEST OF PRE-TEST

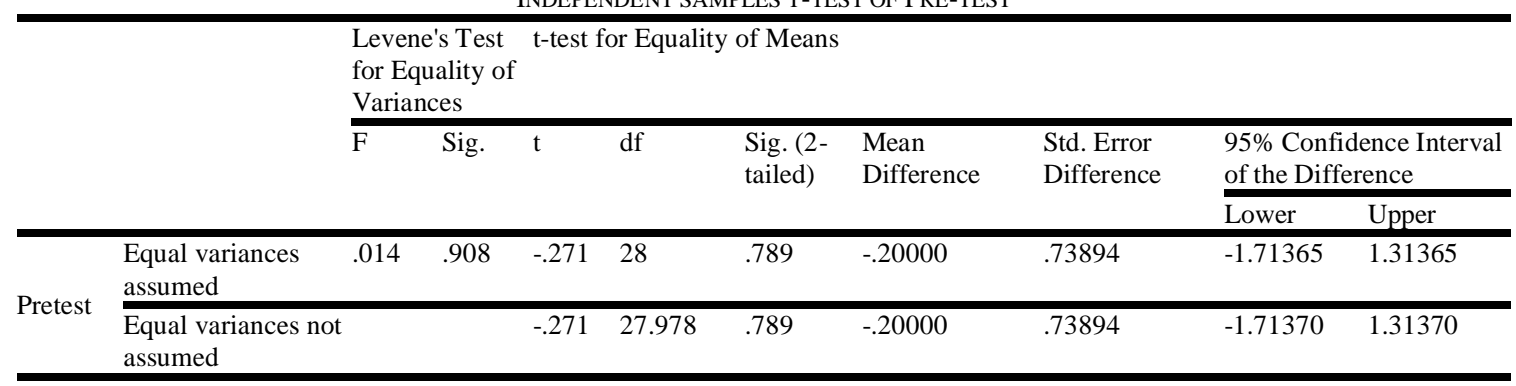

Table 4 indicates, the sig value (2-tailed) for equal variances is .058 which is lower than the required cut-off of .05 . Therefore, it can be said that there is no statistically meaningful difference between the performances of teenager and adult groups in vocabulary learning. In this regard, the first hypothesis of the study is accepted.

TABLE 4

INDEPENDENT SAMPLES T-TEST OF POST-TEST

\begin{tabular}{|c|c|c|c|c|c|c|c|c|c|c|}
\hline & & \multicolumn{2}{|c|}{$\begin{array}{l}\text { Levene's Test for } \\
\text { Equality of Variances }\end{array}$} & \multicolumn{7}{|c|}{ t-test for Equality of Means } \\
\hline & & \multirow[t]{2}{*}{$\mathrm{F}$} & \multirow[t]{2}{*}{ Sig. } & \multirow[t]{2}{*}{$\mathrm{t}$} & \multirow[t]{2}{*}{$\mathrm{df}$} & \multirow[t]{2}{*}{$\begin{array}{l}\text { Sig. (2- } \\
\text { tailed) }\end{array}$} & \multirow[t]{2}{*}{$\begin{array}{l}\text { Mean } \\
\text { Difference }\end{array}$} & \multirow[t]{2}{*}{$\begin{array}{l}\text { Std. Error } \\
\text { Difference }\end{array}$} & \multicolumn{2}{|c|}{$\begin{array}{l}95 \% \text { Confidence Interval } \\
\text { of the Difference }\end{array}$} \\
\hline & & & & & & & & & Lower & Upper \\
\hline \multirow{2}{*}{ Posttest } & $\begin{array}{l}\text { Equal variances } \\
\text { assumed }\end{array}$ & .419 & .523 & 2.567 & 28 & .058 & 1.60000 & .62335 & .32312 & 2.87688 \\
\hline & $\begin{array}{l}\text { Equal variances not } \\
\text { assumed }\end{array}$ & & & 2.567 & 27.618 & .058 & 1.60000 & .62335 & .32232 & 2.87768 \\
\hline
\end{tabular}

\section{Discussion}

Age is a remarkable variable in language teaching and learning. After analyzing the data, different findings have been taken. The first finding was that there was no significant relationship between the performance of teenager and adult groups in their vocabulary learning. Another finding was that there was no significant difference between the performance of teenager and adult groups in their vocabulary learning.

These findings of the present research are in line with some previous research studies. For example, Izura and Ellis (2002), and Schwartz and Katzir (2012) found the educational environment to be a more important factor than the age factor for vocabulary acquisition on the part of learners. Unless attention is also paid to the educational environment, 
including materials, facilities, and teacher quality, commencing EFL education earlier may not have appreciable impact, at least in terms of vocabulary development.

Also this finding was consistent with Shooshtari, Samian and Khazaei's (2013) study. They resulted that age range did not have any significant relationship with vocabulary learning.

\section{CONCLUSION}

As mentioned earlier in this paper, age has been considered a key factor in learning a foreign language. In this regard, the present study attempted to empirically examine the possible relationship between age range and vocabulary learning among pre-intermediate Iranian English as foreign language learners. The results of this study were based of two folds: a) there was no significant relationship between the performance of teenager and adult groups in their vocabulary learning; and b) there was no significant difference between the performance of teenager and adult groups in their vocabulary learning. Although there was no significant relationship between age and vocabulary, according to Ellis (2008), age appears to be a clear factor influencing language learning procedures. The present study shed more light on the concepts of age as an individual factors and vocabulary learning which is considered a skill domain. Iranian EFL teachers and students might find the results of the study beneficial in their process of teaching and learning the English language.

\section{REFERENCES}

[1] Adger, C.T. (2002). What teachers need to know about language. McHenry, IL: Center forApplied Linguistics.

[2] Celce-Marcia, M. (2001). Teaching English as a second or foreign language. Boston Massachusetts: Heine Publishers.

[3] Chen, M. L. (2014). Age differences in the use of language learning strategies. English Language Teaching, 7(2), $144-151$.

[4] Coady, J., \&Huckin, T. (1997). Second language vocabulary acquisition. Cambridge: Cambridge University Press.

[5] De Bot, K., Paribakht, T. S., \&Wesche, M. (1997). Toward a lexical processing model for the study ofsecond language vocabulary acquisition. Studies in Second Language Acquisition, 19, 309-329.

[6] Ebrahimpourtaher, A. \& Eissaie, S. (2015). A survey of Iranian EFL learners' opinions about problems in learning English and as a foreign language learning: The case of vocabulary, grammar, and L1 use in learning L2 skills. Indian Journal of Fundamental and Applied Life Sciences, 5(2), 986-991.

[7] Ellis, R. (2008). The study of second language acquisition ( $2^{\text {nd }}$ ed.). Oxford: Oxford University Press.

[8] Hamidi, H. (2015). Research in applied linguistics. Retrieved October 2017, from http://www.iranelt.com/index.php/introduction-to-research-methods.

[9] Harmer, J. (1991). The practice of English language teaching. Harlow: Longman.

[10] Honby, A. S. (1994). Oxford advanced learners' dictionary. Oxford: Oxford University Press.

[11] Izura, C., \& Ellis, A. (2002). Age of acquisition effects in word recognition and production in first and second languages. Psicologia, 23(1), 245-281.

[12] Kamil, M., \&Hiebert, E. (2005). Teaching and learning vocabulary: Perspectives and persistent issues. In E. Hiebert and M. Kamil (Eds.), Teaching and learning vocabulary: Bringing research to practice (pp. 1-23). Mahwah, NJ: Lawrence Erlbaum.

[13] Larsen-Freeman, D., \& Long, M. (1991). An introduction to second language acquisition research. London: Longman.

[14] Lenneberg, E. (1967). Biological Foundations of Language. New York: Wiley.

[15] Lewis. M. (1993). The Lexical Approach. Hove: Language teaching Publications.

[16] Maftoon, P., Hamidi, H., \& Sarem, S. N. (2012). The effects of CALL on vocabulary learning: A case of Iranian intermediate EFL learners. Broad Research in Artificial Intelligence and Neuroscience, 3 (4), 19-30.

[17] Meara, P. (1980). Vocabulary acquisition: A neglected aspect of language learning. Language Teaching and Linguistics Abstracts, 13, 221-246.

[18] Munoz, C. (2010). On how age affects foreign language learning. Advances in Research on Language Acquisition and Teaching, 39-49. Retrieved June, 2017 from http://www.enl.auth.gr/gala/14th/Papers/Invited\%20Speakers/Munoz.pdf

[19] Nation, I. S. P. (2001). Learning vocabulary in another language. Cambridge: Cambridge University Press.

[20] Nunan, D. (1991). Teaching vocabulary. Language teaching methodology. Hemel Hempstead: Prentice Hall.

[21] Nunan, D. (1999). Second language teaching and learning. Boston: Heinle \&Heinle Publishers.

[22] Penfield, W., \& Roberts, L. (1959). Speech and Brain Mechanisms. Princeton: Princeton University Press.

[23] Ranalli, J. (2003). The treatment of key vocabulary learning strategies in current ELT course books: Repetition, resource use, recording (Unpublished master's thesis). University of Birmingham, United Kingdom.

[24] Read, J. (2000). Assessing vocabulary. Cambridge: Cambridge University Press.

[25] Riazi, A., Sadighi, F., \& Zare, S. (2005). The effect of EFL students'L2 proficiency and age on their overall pattern of vocabulary learning strategy use. IJAL, 8 (2), 90-102.

[26] Richards, J., \& Renandya, W. (2002). Methodology in Language Teaching: An Anthology of Current Practice. Cambridge: Cambridge University press.

[27] Rubin, J. (1987). Learner strategies: Theoretical assumptions, research history and typology. In A. Wenden \& J.Rubin (Eds.), Learner strategies and language learning. Englewood Cliffs: Prentice Hall.

[28] Rubin, J., \& Thompson, I. (1994). How to be a successful language learner. Boston, Massachusetts: Heinle\&Heinle.

[29] Sadeghi, K., \&Taghi Attar, M. (2013). The relationship between learning strategy use and starting age of learning EFL. Procedia- Social and Behavioral Sciences, 70, 387-396.

[30] Sadeghi, M. (2013). The impact of achievement motivation on vocabulary learning in intermediate EFL learners. Journal of Basic and Applied Scientific Research, 3(10), 206-213. 
[31] Sarem, S. N., \& Hamidi, H. (2012). A Critical look at the available literature on the appropriate time to start approaching a second/foreign language. Advances in English Linguistics, 1 (4), 76-79.

[32] Schmitt, N. (2010). Researching vocabulary: a vocabulary research manual. Basingstoke: Palgrave Press.

[33] Schmitt, N., \& McCarthy, M. (1997). Vocabulary, description, acquisition, and pedagogy: Vocabulary learning strategies. Cambridge: Cambridge University Press.

[34] Schwartz, M., \& Katzir, T. (2012). Depth of lexical knowledge among bilingual children. Reading and Writing, 25(8), 19471971.

[35] Shooshtari, Z., Samian, S., \&Khazaei, S. (2013). The impact of individual age differences on the use of EFL vocabulary learning strategies. Journal of Language, Culture, and Translation, 2(1), 103-121.

[36] Singleton, D. (1999). Exploring the Second Language Mental Lexicon. Cambridge: Cambridge University Press.

[37] Stahl, S. A. (2003). Words are learned incrementally over multiple exposures. American Educator, 27(1), 18-22.

[38] Thornbury, S. (2002). How to teach vocabulary. NY: Pearson Educational Limited.

[39] Torras, M. R., Tragant, E., García, M. L. (1997). Croyancespopulairessurl'apprentissageprécoced'une langue étrangère. In C. Muñoz, L. Nussbaum \& M. Pujol (Eds.), Acquisition et interaction en langue étrangère 10 (pp. 127-158).

[40] Whitaker, H., Bub, D., \& Leventer, S. (1981). Neurolinguistic aspects of language acquisition and bilingualism. Annals of the New York Academy of Sciences, 379, 59-74.

[41] Wilkins, D. A. (1972). Linguistics in language teaching. London: EdwardArnold.

[42] Zimmerman, C. B. (1997). Do reading and interactive vocabulary instruction make a difference?: An empirical study. TESOL Quarterly, 31(1), 121-140.

Hamed Barjasteh is an Associate Professor in TEFL. He is a faculty member and the head of English language department at Islamic Azad University, Ayatollah Amoli branch. He has carried out a number of research studies and taken part in a number of conferences and Seminars nationally and internationally. Hamed Barjesteh is an assistant professor in TEFL. He is interested in critical thinking, critical pedagogy and critical discourse analysis. He plans course syllabus to inform students of material assignments and course requirements and he teaches classes according to their needs and schedule. He has a lot of experiences in teaching a wide range of subjects such as testing, research, second language acquisition and etc.

Lida Farsi has been teaching English for about 8 years at different institutes. She is currently a Ph.D. candidate of TEFL in Islamic Azad University, Ayatollah Amoli branch, Iran. She has carried out some research studies, and presented some papers in different conferences and seminars inside and outside the country. Her areas of interest are teaching, education, and psychology. She particularly enjoys collaborating with scientists from different disciplines to develop new skills and solve new challenges. 